\title{
GEOHYDROLOGY AND 1985 GROUND-WATER LEVELS ON MANHASSET NECK, LONG ISLAND, NEW YORK
}

By Robert N. Casson

U.S. GEOLOGICAL SURVEY

Water-Resources Investigations Report 88-4127

Prepared in cooperation with the NASSAU COUNTY DEPARTMENT OF PUBLIC WORKS

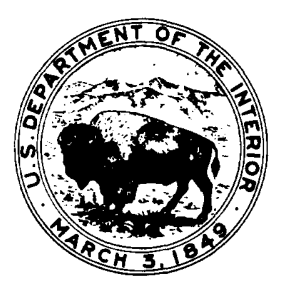

Syosset, New York 
U.S. DEPARTMENT OF THE INTERIOR

MANUEL LUJAN, JR., Secretary

U.S. GEOLOGICAL SURVEY

Dallas L. Peck, Director

For additional information write to:

U.S. Geological Survey

5 Aerial Way

Syosset, New York 11791
Copies of this report may be purchased from:

U.S. Geological Survey Books and Open File Reports Secton Federal Center, BIdg. 810

Box 25425

Denver, CO 80225 


\section{CONTENTS}

Page

Abstract. . . . . . . . . . . . . . . . . . . . . 1

Introduction. . . . . . . . . . . . . . . . . . . . . 1

Purpose and scope. . . . . . . . . . . . . . . . . . . . 1

Location and extent of area. . . . . . . . . . . . . . 3

Geologic history . . . . . . . . . . . . . . . . . . . 3

Previous investigations. . . . . . . . . . . . . . . . . . 4

Methods of investigation . . . . . . . . . . . . . . . . . 4

Geohydrology. . . . . . . . . . . . . . . . . . . . . 4

Recent deposits. . . . . . . . . . . . . . . . . 6

Upper glacial aquifer. . . . . . . . . . . . . . . . 6

Port Washington confining unit . . . . . . . . . . . . . 6

Port Washington aquifer. . . . . . . . . . . . . . . . 7

Magothy aquifer. . . . . . . . . . . . . . . . . . 8

Raritan confining unit... . . . . . . . . . . . . 8

Lloyd aquifer. . . . . . . . . . . . . . . . . . . 8

Bedrock. . . . . . . . . . . . . . . . . . . . . 9

Ground-water levels . . . . . . . . . . . . . . . . . 9

Upper glacial aquifer. . . . . . . . . . . . . . . . . 9

Magothy aquifer. . . . . . . . . . . . . . . . . . . 10

Port Washington aquifer. . . . . . . . . . . . . . . . 10

Lloyd aquifer. . . . . . . . . . . . . . . . . . . . 11

Summary and conclusions. . . . . . . . . . . . . . . . . . . 11

References cited. . . . . . . . . . . . . . . . . . . . . . . 27

Appendix. Ground-water levels on Manhasset Neck, May 29-31, 1985

and related well data. . . . . . . . . . . . . . . 28

\section{ILLUSTRATIONS}

Figure 1. Map of Long Island, N.Y., showing location of

Manhasset Neck. . . . . . . . . . . . . 2

2-7. Maps of Manhasset Neck showing (A) upper surface altitude, and (B) approximate thickness of:

2. Port Washington confining unit. . . . . . . . . 12

3. Port Washington aquifer . . . . . . . . . 14

4. Magothy aquifer . . . . . . . . . . . . 16

5. Raritan confining unit. . . . . . . . . . . 18

6. Lloyd aquifer . . . . . . . . . . . . . 20

7. Bedrock (upper surface altitude only) . . . . . . . 22 


\section{ILLUSTRATIONS (continued)}

Page

Figure 8. Maps of Manhasset Neck showing ground-water levels, May 29-31, 1985:
A. Upper glacial aquifer (water table) . . . . . . . . 23
B. Magothy aquifer (potentiometric surface). . . . . . . 24
C. Port Washington aquifer (potentiometric surface). . . . 25
D. Lloyd aquifer (potentiometric surface). . . . . . . . 26

\section{TABLE}

Table 1. Summary of geologic and geohydrologic units on

Manhasset Neck .. . . . . . . . . . . . . . .

\section{PLATES \\ (in pocket)}

Plate 1. Map showing the location of wells, test holes, and lines of geohydrologic sections.

2. Geohydrologic sections $A-A^{\prime}, B-B^{\prime}, C-C^{\prime}$, and $D_{-} D^{\prime}$.

\section{Conversion Factors and Abbreviations}

Multiply inch-pound unit

foot ( $f t)$

mile ( $\mathrm{mi}$ )

square mile $\left(\mathrm{mi}^{2}\right)$ by

To obtain metric unit

0.3048

1.609

2.590

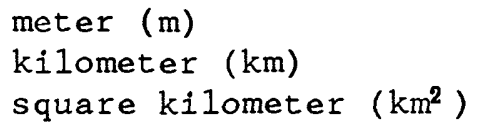

Sea level: In this report "sea level" refers to the

National Geodetic Vertical Datum of 1929 (NGVD of 1929)--

a geodetic datum derived from a general adjustment of the

first-order level nets of both the United States and

Canada, formerly called "Sea Level Datum of 1929." 


\title{
GEOHYDROLOGY AND 1985 GROUND-WATER LEVELS ON MANHASSET NECK, \\ LONG ISLAND, NEW YORK
}

by Robert N. Casson

\begin{abstract}
Manhasset Neck, a 13.4-square-mile peninsula on the north shore of Nassau County, N.Y., consists of unconsolidated Pleistocene and Cretaceous sediments overlying a basement complex of Precambrian and(or) early Paleozoic age. It also contains beach, bog, and marsh deposits of Holocene age. A glacial advance during the Woodfordian Substage caused deformation and displacement of Pleistocene and Cretaceous material. Cretaceous material overlies bedrock in the southern half of the peninsula but is generally absent in the northern half. The Cretaceous material forms the Lloyd and Magothy aquifers, which are separated by the Raritan confining unit. The northern half of Manhasset Neck contains the upper Pleistocene Port Washington confining unit, underlain by the Port Washington aquifer, which unconformably overlies bedrock. The upper glacial aquifer, also of late Pleistocene age, overlies the entire peninsula. An upward bulge of the "ice-shoved" Port Washington confining unit maintains an anomalously high water table near the center of Manhasset Neck.
\end{abstract}

\section{INTRODUCTION}

All freshwater for public supply and industrial, agricultural, and commercial use in central and eastern Long Island is ground water. Eastward urbanization on the island, particularly since the 1950's, has placed an increasing demand on the ground-water resources.

Manhasset Neck, a 13.4-mi2 (square-mile) peninsula in the Town of North Hempstead, Nassau County (fig. 1), has a population of 39,000. Because little is known about the geohydrologic environment, development and management of the ground-water resources for future demand requires a detailed description of the geohydrologic setting.

In 1985, the U.S. Geological Survey, in cooperation with the Nassau County Department of Public Works, studied Manhasset Neck to document the geohydrology and define ground-water levels.

\section{Purpose and Scope}

This report describes the geohydrology and 1985 ground-water levels on Manhasset Neck. It includes (1) maps showing the surface altitude and thickness of the aquifers and confining units; (2) four vertical sections that 
depict the positions of these hydrogeologic units, and (3) water-table and potentiometric-surface maps of the aquifers. An appendix gives water-level data measured in 66 wells during May 29-31, 1985.

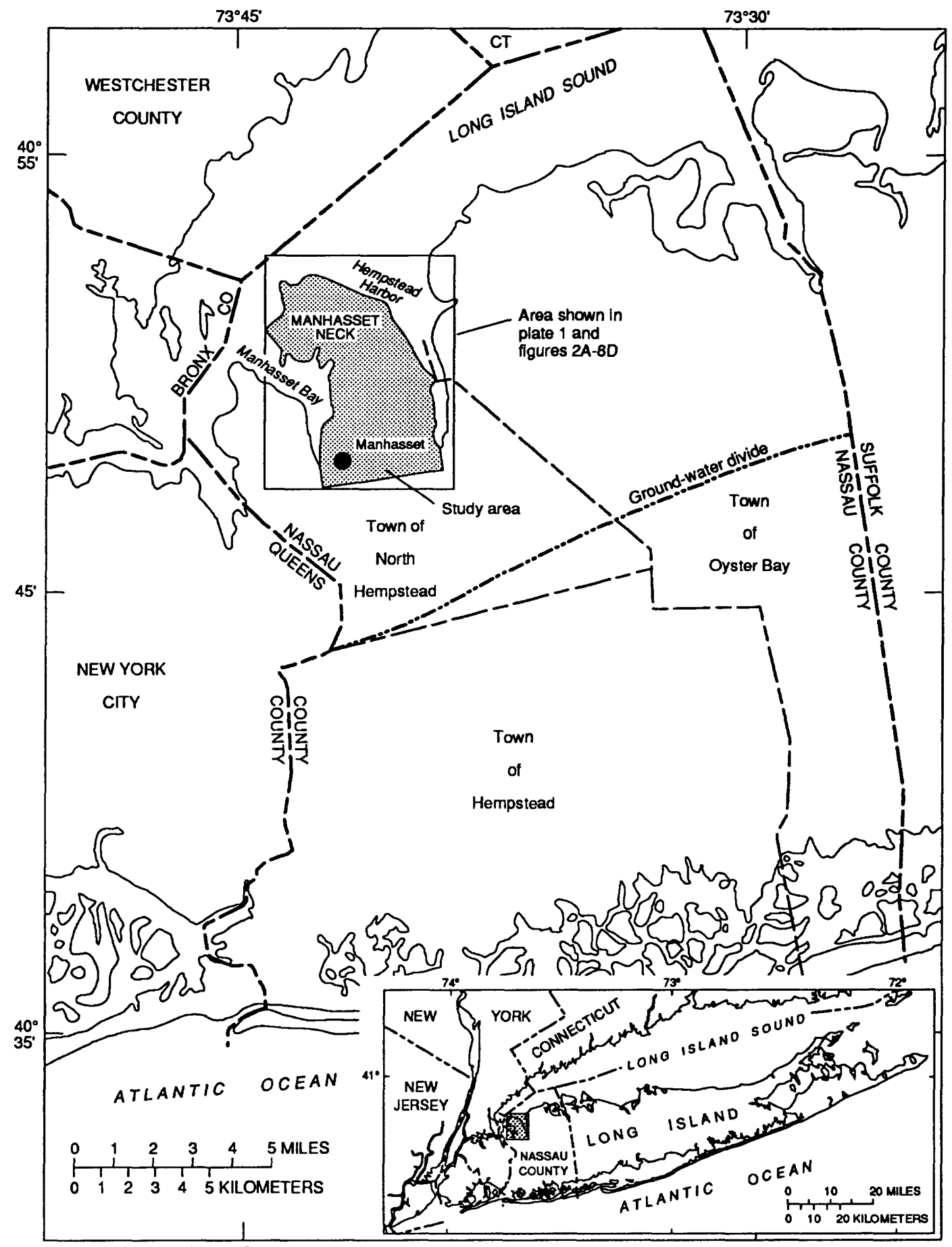

Base from U.S. Geological Survey

1:250,000 series, New York, 1960

Figure 1.--Location of Manhasset Neck, Nassau County, N.Y. 


\section{Location and Extent of Area}

The area investigated is a $13.4-\mathrm{mi}^{2}$ peninsula in the Town of North Hempstead in northern Nassau County. It is bounded on the west, north, and east by Manhasset Harbor, Long Island Sound, and Hempstead Harbor, respectively, and by Northern Boulevard on the south (fig. 1).

\section{Geologic History}

A detailed description of Long Island's geologic history is presented in Fuller (1914). Recent evidence has prompted a reinterpretation of the island's glacial history, however, which is given in Sirkin (1982).

Oliver and Drake (1951), in a seismic study of the Long Island area, demonstrate that the Precambrian and (or) early Paleozoic bedrock surface has topographic irregularities that are indicative of subareal erosion. This period of erosion may have begun in the Late Triassic Period and extended into the Jurassic. A mid-Cretaceous uplift of the earth's crust, centered along the axis of the Appalachian Mountains, subsequently created highlands to the west and north of Long Island in northern New York, Vermont, and New Hampshire while depressing the Long Island area southeastward. This orogenic movement provided a source of sediment that was subsequently deposited in the Long Island area as the Raritan Formation and Magothy Formation and Matawan Group, undifferentiated. Grain-size analysis of the Cretaceous sediments indicates an estuarine or deltaic environment of deposition (Mills and Wells, 1974). The southeastward thickening of the Cretaceous formations indicates renewed tilting of the bedrock (Swarzenski, 1963). Regression of the sea at the close of the Cretaceous Period is indicated by a lack of Tertiary strata and the presence of troughs that seem to be river valleys cut into Cretaceous sediment. The depression that now forms Long Island Sound probably originated as an east-west-trending subsequent river valley, the southern extent of which is represented by a cuestalike ridge cut into the Cretaceous formations (Swarzenski, 1963).

A Pleistocene periglacial deflation surface, as indicated by quartz ventifacts in the top of Cretaceous sediment at the Port Washington sand pits near the east-central shore of the peninsula, resulted from the ensuing glacial activity (Mills and Wells, 1974). A new conceptual model for the glaciation of this region has been developed in response to evidence of a nonglacial interval and subsequent high stand of the sea during the mid-Wisconsinan Stage between the emplacement of two drift sheets (Sirkin, 1982). The earlier of these drift sheets consists of the Flower Hill sand and West Shore till units of the Manhasset Formation that forms the Port Washington aquifer and was deposited during the first glacial advance, which apparently occurred during the Altonian Substage (Sirkin, 1982). This deposit seems to be derived largely from a Cretaceous source because it contains only a minor amount of erratic material. The second drift sheet consists of the Hempstead sand and Roslyn till units of the East Hills Formation that forms the upper glacial aquifer and was deposited during the second glacial advance during the Woodfordian Substage (Sirkin, 1982). Ice-shove tectonics during this time resulted in the deformation and displacement of Cretaceous and Pleistocene sediments (Mills and Wells, 1974). 
At the end of glaciation in the Woodfordian Substage (Sirkin, 1982) approximately 18,000 years ago, sea level began to rise to its present level. Consequently, recent deposition of Holocene age consisting of shore, stream, valley, swamp, lake, bog, and marsh deposits has occurred.

\section{Previous Investigations}

The geology and ground-water resources of Nassau County were described by Perlmutter and Geraghty (1963), Swarzenski (1963), Isbister (1966), and Kilburn (1979). The reports by Swarzenski and Kilburn provided information pertinent to Manhasset Neck such as historic water-level data and contour maps. The glacial deformation of the area was described by Mills and Wells (1974). Sirkin (1982) described the surficial geology, geologic history, geologic nomenclature, and correlation of Pleistocene deposits on Long Island. Perlmutter and Todd (1965) and Sirkin (1974) discussed the correlation of Cretaceous strata.

\section{Methods of Investigation}

Drillers' and geologists' lithologic strip logs of the earth material penetrated were compared for correlation purposes. Many of these logs represent observation wells suitable for water-level measurements. Gamma logs from some wells were available to verify drillers' or geologists, interpretations. Locations of wells and test holes are shown on plate 1.

Data on ground-water levels collected from 1950 through May 1985 were analyzed. (The most recent water-level measurements were made during this study, on May 29-31, 1985.) Because the water levels in the deep, confined aquifers (Lloyd and Port Washington aquifers) change in response to tidal variations, all measurements were made at high tide for consistency. In addition, all public-supply wells were measured after a shutdown period of at least 12 hours to allow recovery, except for Lloyd well N1715 in the central part of Manhasset Neck (p1. 1), which had been running for 24 hours. As such, the potentiometric surface is not static but reflects the degree of confinement of the Lloyd aquifer, as evidenced by the far-reaching effects of the stress placed on it by withdrawal.

\section{GEOHYDROLOGY}

Long Island is underlain by unconsolidated sediments of Quaternary and Cretaceous age resting on a bedrock surface of Precambrian and (or) early Paleozoic age. Material of the Cretaceous Period consists of the Raritan Formation, which is composed of a lower Lloyd Sand Member and an upper unnamed clay member, and the Magothy Formation and Matawan Group, undifferentiated. The Pleistocene material consists of two sand units, the Manhasset Formation and Sirkin's (1982) East Hills Formation, separated by a marine clay unit.

Pleistocene stratigraphy of Long Island has been the subject of much confusion. Fuller (1914) terms the lower sand unit and middle clay unit of Manhasset Neck the Jameco Gravel and Gardiners Clay, respectively. A 
pre-Wisconsinan age is suggested for the Jameco Gravel, whereas the Gardiners Clay is thought to represent the later Sangamon interglaciation (Fuller, 1914). Kilburn (1979) suggests the names Port Washington aquifer and Port Washington confining unit for the Jameco Gravel and Gardiners Clay on Manhasset Neck, respectively, on the grounds that the names Jameco Gravel and Gardiners Clay imply a questionable correlation with other units of that designation in other parts of Long Island. Recent studies by Sirkin (1982) suggest that Fuller's middle clay unit (which Sirkin designates marine clay), herein referred to as the Port Washington confining unit, represents a warm interval and a relatively high stand of the sea during the mid-Wisconsinan Stage. This warm interval occurred between the emplacement of two drift sheets, hereafter referred to as the Port Washington aquifer and upper glacial aquifer, for the lower and upper sand units, respectively.

The question of stratigraphic correlation is not of paramount importance here because the upper and lower boundaries of hydrogeologic units are determined by lithology, not by age. For example, the top of the Port Washington confining unit is distinguished from the upper glacial aquifer by a change from sand to clay, which may not have time-stratigraphic significance. A summary of the geologic and corresponding geohydrologic units is given in table 1 .

Table 1.--Summary of geologic and geohydrologic units on Manhasset Neck, N.Y.

[G, glacial advance; I, interglacial recession. Modified from Sirkin (1982) and Kilburn (1979)]

\begin{tabular}{|c|c|c|c|c|c|c|}
\hline System & \multicolumn{4}{|c|}{ Series, stage, substage } & $\begin{array}{l}\text { Geologic } \\
\text { unit }\end{array}$ & $\begin{array}{c}\text { Geohydrologic } \\
\text { unit }\end{array}$ \\
\hline \multirow{4}{*}{ Quaternary } & \multicolumn{4}{|c|}{ Holocene } & $\begin{array}{l}\text { Shore, beach, marsh } \\
\text { bog, lake, stream }\end{array}$ & Recent deposits \\
\hline & \multirow{3}{*}{ Pleistocene } & \multirow{3}{*}{ 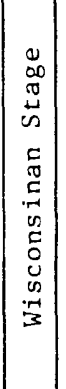 } & \multirow{3}{*}{$\begin{array}{l}0 \\
\infty \\
0 \\
0 \\
0 \\
0 \\
0 \\
0\end{array}$} & Woodfordian(G) & $\begin{array}{l}\text { East Hills Formation } \\
\text { Roslyn till unit } \\
\text { Hempstead sand unit } \\
\end{array}$ & $\begin{array}{c}\text { Upper glacial } \\
\text { aquifer }\end{array}$ \\
\hline & & & & $\begin{array}{l}\text { Farmdalian(I) } \\
\text { Portwashington(I) }\end{array}$ & Marine clay & $\begin{array}{l}\text { Port Washington } \\
\text { confining unit }\end{array}$ \\
\hline & & & & Altonian(G) & $\begin{array}{l}\text { Manhasset Formation } \\
\text { West Shore till unit } \\
\text { Flower Hill sand unit }\end{array}$ & $\begin{array}{c}\text { Port Washington } \\
\text { aquifer }\end{array}$ \\
\hline \multirow[b]{2}{*}{ Cretaceous } & \multirow{2}{*}{\multicolumn{4}{|c|}{ Upper Cretaceous }} & $\begin{array}{l}\text { Matawan Group and } \\
\text { Magothy Formation, } \\
\text { undifferentiated }\end{array}$ & Magothy aquifer \\
\hline & & & & & $\begin{array}{l}\text { Raritan Formation } \\
\text { Unnamed clay member } \\
\text { Lloyd Sand member }\end{array}$ & $\begin{array}{l}\text { Raritan } \\
\text { confining unit } \\
\text { Lloyd aquifer }\end{array}$ \\
\hline $\begin{array}{l}\text { Paleozoic } \\
\text { and (or) } \\
\text { Precambrian }\end{array}$ & & & & & Bedrock & Bedrock \\
\hline
\end{tabular}




\section{Recent Deposits}

Recent deposits of Holocene age consist of sand and gravel that forms beaches and bars and silty alluvium deposited by streams. Organic silt in freshwater swamps and peat bogs apparently represents continuous deposition since early postglacial time (Swarzenski, 1963). Swarzenski (1963) notes an age of $5,310 \pm 240$ year BP (before present) for partly lignitized plant debris from a humus and peat deposit overlying and in contact with till in the study area.

Clay and silt deposits beneath Long Island Sound and the bays that flank Manhasset Neck are important hydrologically because they retard the downward movement of saltwater and thus inhibit its movement into Manhasset Neck's ground-water reservoir.

\section{Upper Glacial Aquifer}

The upper glacial aquifer forms the present land surface on Manhasset Neck except in areas that have experienced recent deposition, such as the shore and its bays, marshes, bogs, lakes, and streams. The upper glacial aquifer includes both the unsaturated and saturated parts of the upper Pleistocene deposits. As shown in plate 2, these deposits overlie the Port Washington confining unit in the northern half of Manhasset Neck and overlie the Magothy Formation in the southern part.

Drillers' and geologists' logs indicate that the deposits consist of beds of brownish, fine to coarse stratified sand and gravel and unstratified mixtures of clay and boulder till. Freshwater-lake deposits consisting of silt, clay, lignite, and pyrite nodules are also present locally.

The upper glacial aquifer in the study area conforms to the moraine area of Swarzenski (1963), who erroneously divided the upper Pleistocene deposits of Long Island into a northern moraine area and a southern area of glacial outwash. Sirkin (1982) classifies the kamic stratified sand and gravel and the gravel and unstratified clay and boulder mixture on Manhasset Neck as the Hempstead sand and Roslyn till units, respectively, of his Woodfordian East Hills Formation. Furthermore, as demonstrated by Mills and Wells (1974), the late Wisconsin ice advance caused large-scale folding and thrust faulting of the previously deposited Cretaceous and Pleistocene material.

The top of the upper glacial aquifer ranges from approximately $200 \mathrm{ft}$ above to $140 \mathrm{ft}$ below sea level; its thickness ranges from 0 to approximately $340 \mathrm{ft}$. The vertical sections in plate 2 show its position in relation to the other geohydrologic units.

\section{Port Washington Confining Unit}

The name Port Washington confining unit was introduced by Kilburn (1979) to avoid the use of the name Gardiners Clay, which would cause confusion in correlations. In some locations this unit contains fossil oyster and clam shells and foraminifera, of which Elphidium is the most common genus. Radiocarbon age determinations of oyster-shell fragments by the U.S. Geological 
Survey and reported by Swarzenski (1963) indicate an age greater than 38,000 years. Sirkin (1982) reports a range in age from 43,000 to 21,750 BP for a sequence of marine clay, salt-and freshwater peat, and oyster-reef beds that occur within this unit at the Port Washington sand pits in the east-central part of Manhasset Neck (fig. 1).

The Port Washington confining unit overlies the Port Washington aquifer and is in turn overlain by the upper glacial aquifer. Insofar as it abuts the Cretaceous deposits on its south side ( 1 1. 2, section $\left.D^{-} D^{\prime}\right)$, Suter and others (1949) correlated it with the Raritan Formation; Kilburn (1979) states that this unit probably contains local remnants of the Raritan Formation. In addition, clayey till and clay/silt of glacial origin are present within this unit in the "glacial tectonic" manner suggested by Mills and Wells (1974).

The top of the Port Washington confining unit ranges from $104 \mathrm{ft}$ above to $150 \mathrm{ft}$ below sea level (fig. 2A), and its thickness ranges from 30 to $264 \mathrm{ft}$ (fig. 2B). The vertical sections in plate 2 show its position in relation to the other geohydrologic units in the area.

Drillers' and geologists' logs indicate this unit to consist of gray and greenish-brown clay and silt in addition to the fossiliferous material mentioned previously. It also contains scattered lenses of sand or sand and gravel.

\section{Port Washington Aquifer}

The name Port Washington aquifer was first used for the area by Kilburn (1979) in preference to the name Jameco Gravel, which would imply a correlation with Jameco deposits in southern Queens and southwestern Nassau Counties. Furthermore, Swarzenski (1963) noted that this deposit, which has not been reliably dated, seems to be derived largely from a Cretaceous source and thus contains only a small amount of erratic material, such as igneous rock pebbles, that characterize the Jameco on the south shore. More recent studies by Sirkin (1982) suggest that this Quaternary unit, which was previously hypothesized to represent a pre-Wisconsinan glacial deposit, is probably representative of the Altonian Substage of the Wisconsinan Stage.

The Port Washington aquifer is present only in the northern half of Manhasset Neck, where it lies upon the bedrock surface and is in turn overlain by a clay unit termed the Port Washington confining unit (Kilburn, 1979). In the southern part it abuts the buried Cretaceous cuesta. Kilburn (1979) notes that not all Cretaceous deposits were removed from the area north of their inferred limits; thus, erosional remnants of Cretaceous material could be present between the Pleistocene deposits and the bedrock in this area.

The top of the Port Washington aquifer ranges from approximately $15 \mathrm{ft}$ to $275 \mathrm{ft}$ below sea level (fig. $3 \mathrm{~A}$ ); its thickness ranges from 0 to $140 \mathrm{ft}$ (fig. 3B). The vertical sections in plate 2 show its position in relation to the other hydrogeologic units in the area.

Drillers' and geologists' logs indicate that this unit is composed mainly of sand or sand and gravel with varying amounts of interbedded clay, silt, and sandy clay. It generally is brownish, which helps to distinguish it from the whitish Cretaceous sediment. 


\section{Magothy Aquifer}

The Magothy aquifer, which consists of Upper Cretaceous sediment of the Magothy Formation and Matawan Group, undifferentiated, overlies the Raritan Formation and is in turn overlain by Pleistocene glacial deposits. The altitude of the top of the Magothy on Manhasset Neck ranges from $53 \mathrm{ft}$ above to $173 \mathrm{ft}$ below sea level (fig. 4A); thickness ranges from 0 to $311 \mathrm{ft} \mathrm{fig}$. 4B). Together with the underlying Cretaceous Raritan Formation it forms an erosional feature resembling a buried cuesta ( $p 1.2$, section $A-A^{\prime}$ ) and thus is absent from the northern half of the area. Plate 2 also shows the position of the Magothy aquifer in relation to the other geohydrologic units in the area.

Drillers' and geologists' logs typically indicate a fining upward sequence of grain size. A greater proportion of gravel is common in the lower half of the formation, whereas clay and sandy clay predominate in the upper half. The coarser, lower zone is commonly referred to in the literature as "basal" Magothy. The chief constituent is fine micaceous quartz sand, generally white, although gray, pink, or red sediment is common.

The Magothy aquifer is the principal aquifer throughout most of Long Island, including Manhasset Neck.

\section{Raritan Confining Unit}

The Raritan confining unit, which consists of the unnamed clay member of the Raritan Formation, lies between the Lloyd and Magothy aquifers and acts as a confining unit to the underlying Lloyd aquifer. Like the Lloyd aquifer below, it dips and thickens southeastward. The altitude of the top of the Raritan ranges from 150 to $275 \mathrm{ft}$ below sea level (fig. 5A), and its thickness ranges from 25 to $140 \mathrm{ft}$ (fig. 5B). The position of the Raritan confining confining unit in relation to the other geohydrologic units is shown in the vertical sections in plate 2 .

Drillers' and geologists' logs describe the material as a relatively impermeable solid and silty clay that can be light to dark gray, red, white, yellow, or mottled. Laminations as well as pyrite and lenses of lignite are present in some cores.

\section{Lloyd Aquifer}

Overlying the bedrock is the Lloyd aquifer, which consists of the Lloyd Sand Member of the Upper Cretaceous Raritan Formation. As in the bedrock below, its upper surface has a general southeastward dip, as indicated by the logs of 13 wells drilled into this member (fig. 6A). The altitude of the top of the Lloyd ranges from approximately 200 to $400 \mathrm{ft}$ below sea level, and the thickness is generally $150 \mathrm{ft}$ (fig. 6B). It is absent from the northern half of the study area, where it abuts Pleistocene deposits, as shown in figures $6 \mathrm{~A}$ and $6 B$ and the vertical sections in plate 2 .

Drillers' and geologists' logs indicate that Lloyd material consists of yellow, white, and gray subangular to subrounded quartz with minor amounts of chert and other stable minerals; it also contains interstitial clay as well as 
lenses of white, gray, or multicolored clay that cannot be correlated over significant distances. Lignite is present as scattered particles or thin lenses. Grain-size analyses suggest an estuarine or deltaic depositional environment (Mills and Wells, 1974).

\section{Bedrock}

The bedrock surface in the study area lies between $166 \mathrm{ft}$ and $400 \mathrm{ft}$ below sea level (fig. 7). The exact depth of the bedrock is difficult to distinguish in logs because its surface is weathered to sapprolite. Drillers' and geologists' interpretation of the weathered surface is based upon residual red, gray, yellow, white, green, or mottled clay or partly decayed rock and mineral fragments. Quartz, garnet, biotite, amphibole, and feldspar characterize the mineral-fragment assemblage, which seems indicative of a biotite schist or gneiss with possible granitic or pegmatitic intrusives (Perlmutter and Geraghty, 1963).

The bedrock-surface altitude and configuration are of interest because the bedrock essentially forms the base of the ground-water reservoir. Although joints and fractures in the bedrock could possibly provide yields suitable for limited domestic supply, no wells obtain water from this source in the study area at present.

The 11 wells and 4 test holes that have been drilled into bedrock in the study area (fig. 1) define a southeastward dip except for well N314, at the northern end of the peninsula, which indicates a local northwestward dip ( -190 value on fig. 7). Although the limited well data can indicate only the general trend of the bedrock surface, Oliver and Drake (1951), in a seismic study of the Long Island area, found indications of 200 to $300 \mathrm{ft}$ of bedrock relief; thus, the bedrock surface clearly is not a classic peneplain.

\section{GROUND-WATER LEVELS}

The circulation of water from the earth's surface to the atmosphere by evaporation and transpiration and its subsequent return as precipitation constitutes the hydrologic cycle. Of the total precipitation that falls on Manhasset Neck, part returns to the atmosphere through evapotranspiration, part runs overland to streams that discharge to Long Island Sound, and the remainder, approximately 50 percent, infiltrates the ground to the zone of saturation, where it becomes part of Manhasset Neck's ground-water system.

\section{Upper Glacial Aquifer}

The water table lies generally within the upper glacial aquifer on Manhasset Neck. Its configuration is essentially controlled by the land-surface topography, the water-transmitting properties of the upper Pleistocene deposits in which it lies and of the geohydrologic units below, and the location and amount of pumping from wells screened within Manhasset Neck's geohydrologic units. 
Water-level measurements made at 32 wells throughout Manhasset Neck on May 29-31, 1985, were used to construct the water-table map shown in figure 8A. The maximum water-table altitude in the area was $110 \mathrm{ft}$ above sea level near the center of Manhasset Neck. Section $A-A^{\prime}$ (p1. 2) shows a bulge in the Port Washington confining unit near the center of the study area; this bulge seems to retard the northward flow of ground water. An increase in head is needed for water to permeate the confining unit and continue its northward flow, which begins approximately 3 miles to the south at Long Island's regional ground-water divide (fig. 1). This anomaly gives the geohydrologic system of Manhasset Neck a degree of complexity that is not found elsewhere on Long Island.

\section{Magothy Aquifer}

The Magothy aquifer (fig. 8B) is the major source of water for Manhasset Neck as well as the rest of Long Island. It underlies the upper glacial aquifer and is hydraulically continuous with it. The major criterion for differentiating the Magothy from the upper glacial aquifer above is its finer sediment size. The Magothy also is in hydraulic contact with the Port Washington aquifer ( 1 1. 2). Its general fining upwards sequence suggests that it is confined at depth. The Port Washington confining unit provides increased confinement in the northern part of the area (p1. 2, section $\left.D_{-} D^{\prime}\right)$.

Water-level data were collected on May 29-31, 1985, from seven wells screened within the Magothy aquifer. The distribution of hydrostatic heads (fig. $8 \mathrm{~B}$ and $\mathrm{p} 1.2$ ) indicates a downward vertical flow gradient from the upper glacial aquifer above at Manhasset Neck's central and southeastern areas of recharge. The potentiometric-surface altitude ranges from $39 \mathrm{ft}$ to $10 \mathrm{ft}$ above sea level at the south-central and southwestern parts of the Manhasset Neck, respectively.

\section{Port Washington Aquifer}

The Port Washington aquifer and the Lloyd aquifer together form what has been described in the literature as the deep confined aquifer because of the probable lateral connection between the two units (Swarzenski, 1963).

Water-level data from only 11 wells screened within the unit were available for construction of the potentiometric-surface contours shown in figure $8 \mathrm{C}$. The vertical sections in plate 2 indicate flowing wells along the shores of the study area, where hydrostatic heads of the aquifer are higher than the land surface. Recharge from upper units through the Port Washington confining unit in inland areas is possible because the hydrostatic heads above are approximately $60 \mathrm{ft}$ greater. The altitude of the potentiometric surface ranges from $27 \mathrm{ft}$ above sea level near the central part of the study area to almost $1 \mathrm{ft}$ below sea level at the western shore. 


\section{Lloyd Aquifer}

The Lloyd aquifer is the most confined unit in the study area and thus probably is the least contaminated source of water, as well as the most unstable in terms of pumping interference.

Water-level data obtained on May 29-31, 1985 from nine wells screened within the unit were used to construct the potentiometric-surface map in figure 8D. The dynamic equilibrium of the unit under natural conditions has been altered by pumping from public-supply well N1715. The relation between hydrostatic heads in the Lloyd aquifer and those of the other aquifers is shown in the vertical sections in plate 2. As shown in plate 2 and figure $8 D$, the Lloyd aquifer has a potential for saltwater encroachment where its potentiometric surface is below sea level near the western shore of the peninsula. The highest potentiometric-surface altitude on Manhasset Neck is $14 \mathrm{ft}$ above sea level at the east shore (p1. 2, section $\left.D^{\prime} D^{\prime}\right)$.

\section{SUMMARY AND CONCLUSIONS}

Manhasset Neck is composed of unconsolidated sediments of Pleistocene and Cretaceous age resting on a Precambrian and (or) early Paleozoic bedrock surface. A late Wisconsinan ice advance produced extensive folding and thrust faulting of Cretaceous and Pleistocene material that makes the geohydrologic environment anomalously complex for Long Island.

Upper Cretaceous material (which overlies bedrock in the southern half of the study area but is generally absent from the northern half) forms the Raritan Formation and Magothy Formation and Matawan Group, undifferentiated. The Raritan Formation consists of the Lloyd Sand Member (the Lloyd aquifer) and an overlying unnamed clay member (the Raritan confining unit). The Magothy Formation and Matawan Group, undifferentiated, forms the Magothy aquifer, which overlies the Raritan confining unit.

The Port Washington aquifer and overlying Port Washington confining unit, both upper Pleistocene in age, are present beneath the northern half of the peninsula, where they overlie bedrock and abut the Cretaceous material to the south. Overlying these units throughout the area is the upper glacial aquifer, also of upper Pleistocene age. The upper glacial aquifer forms the present land surface except in areas of recent deposits of Holocene age, such as the shore and its bays, and marshes, bogs, lakes, and streams.

Water-level data reveal a relatively high water table for Long Island near the center of Manhasset Neck; this is probably the result of an upward bulge in the underlying "ice-shoved" Port Washington confining unit. 


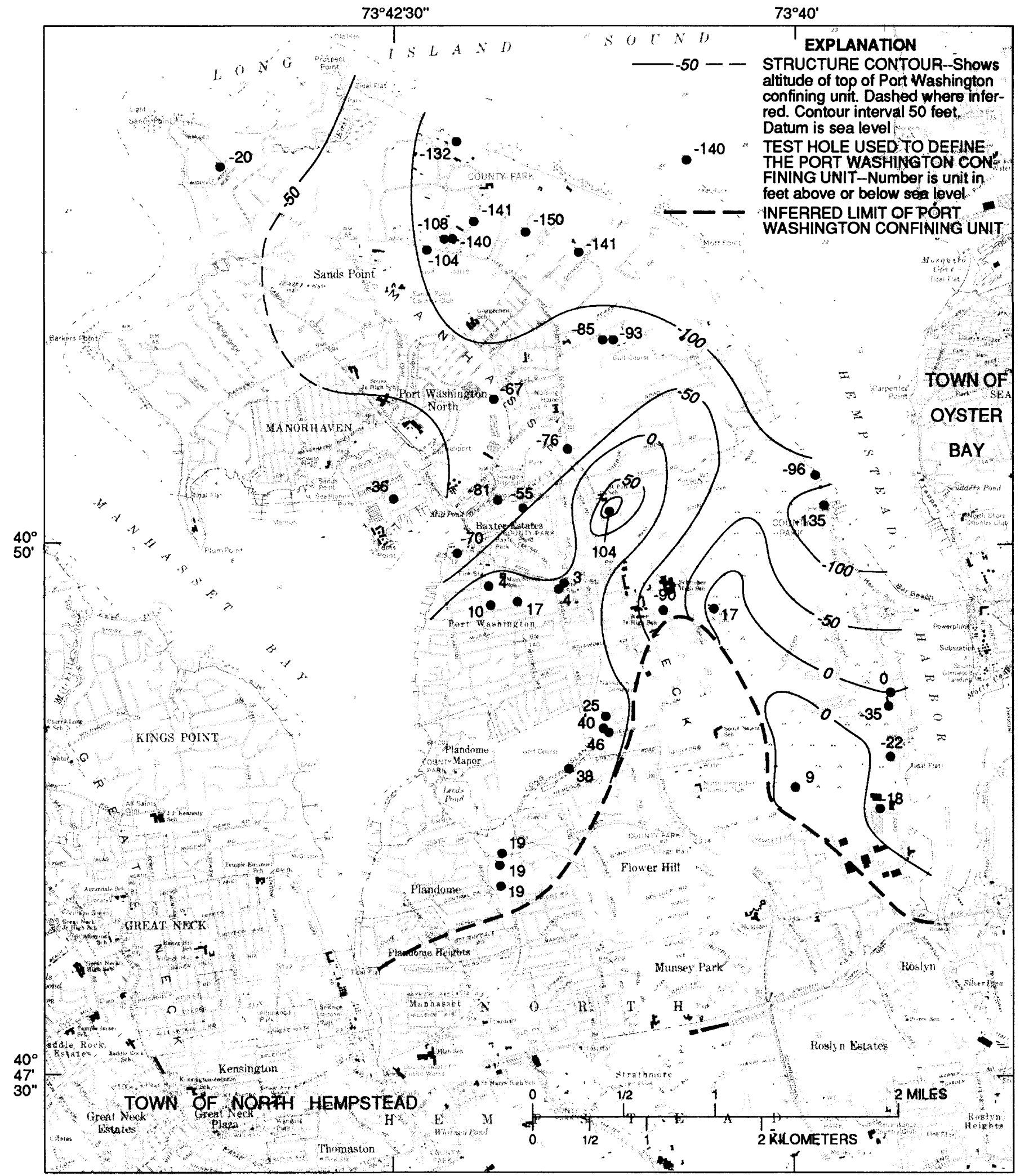

Base from New York State Department of Transportation Sea Cliff, N.Y., 1:24,000, 1981

Figure 2A.--Altitude of the top of the Port Washington confining unit beneath Manhasset Neck. (Location is shown in fig. 1.) 


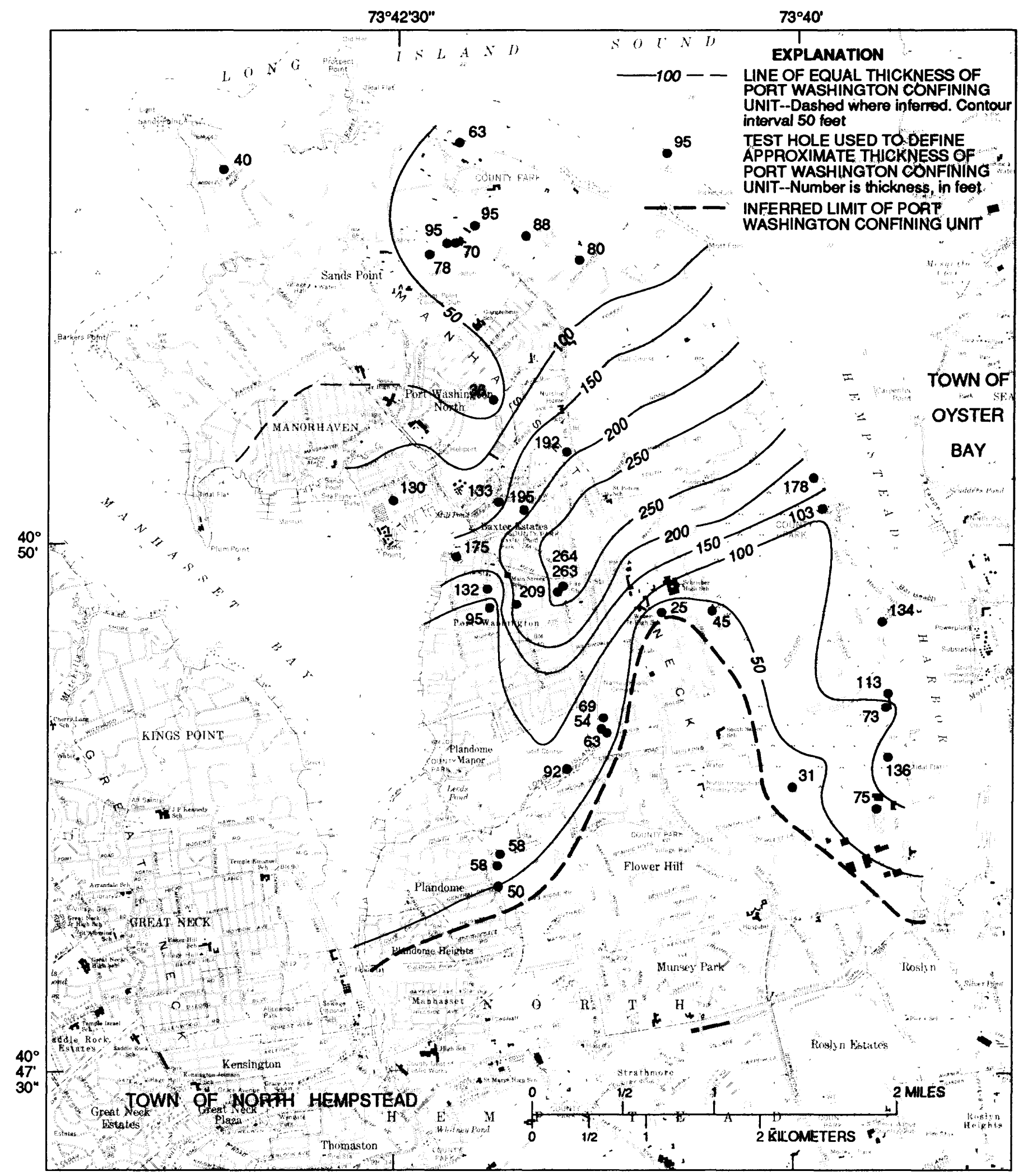

Base from New York State Department of Transportation Sea Cliff, N.Y., 1:24,000, 1981

Figure 2B.--Approximate thickness of the Port Washington confining unit beneath Manhasset Neck. 


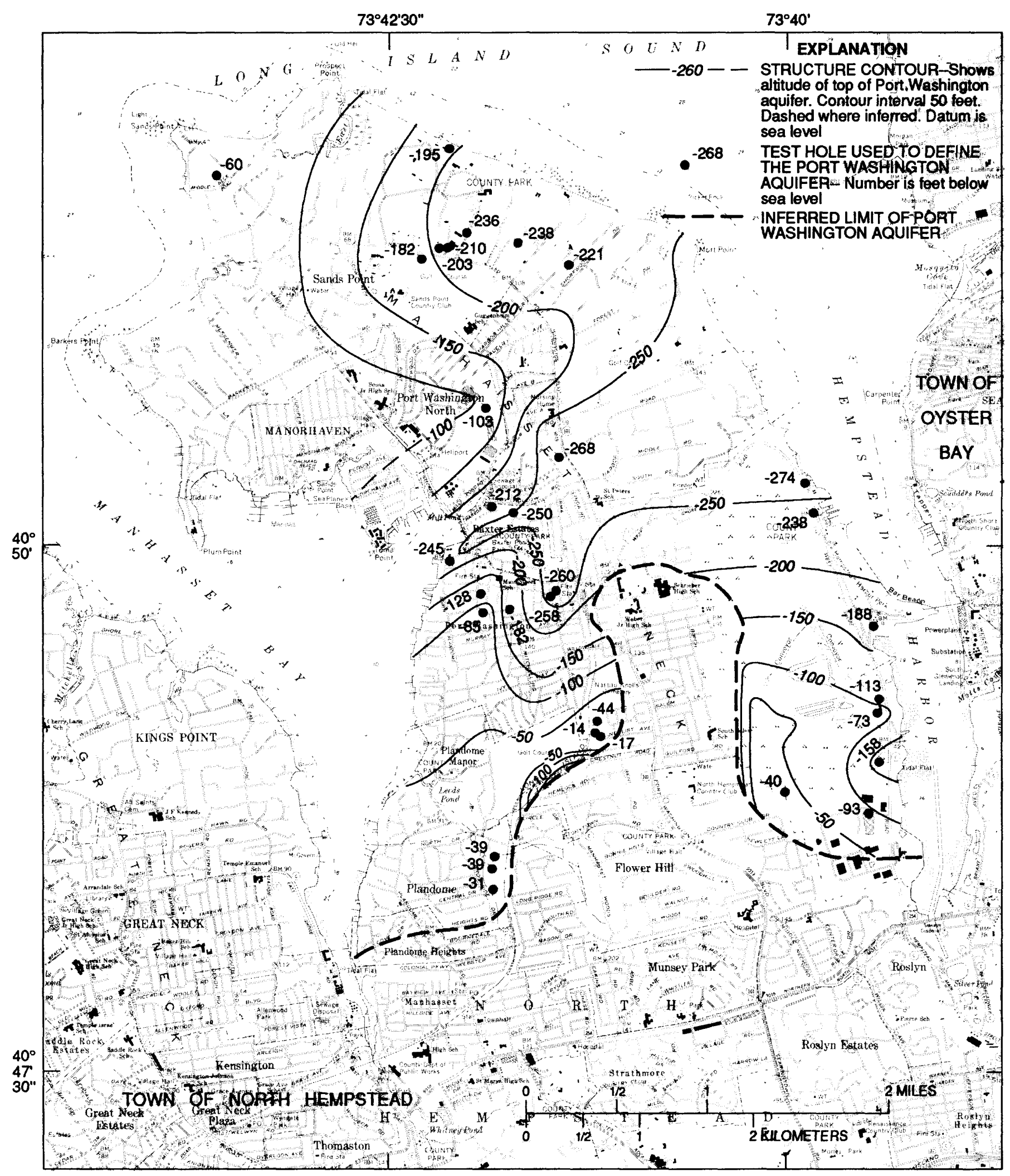

Base from New York State Department of Transportation Sea Cliff, N.Y., 1:24,000, 1981

Figure SA.--Altitude of the top of the Port Washington aquifer beneath Manhasset Neck. 


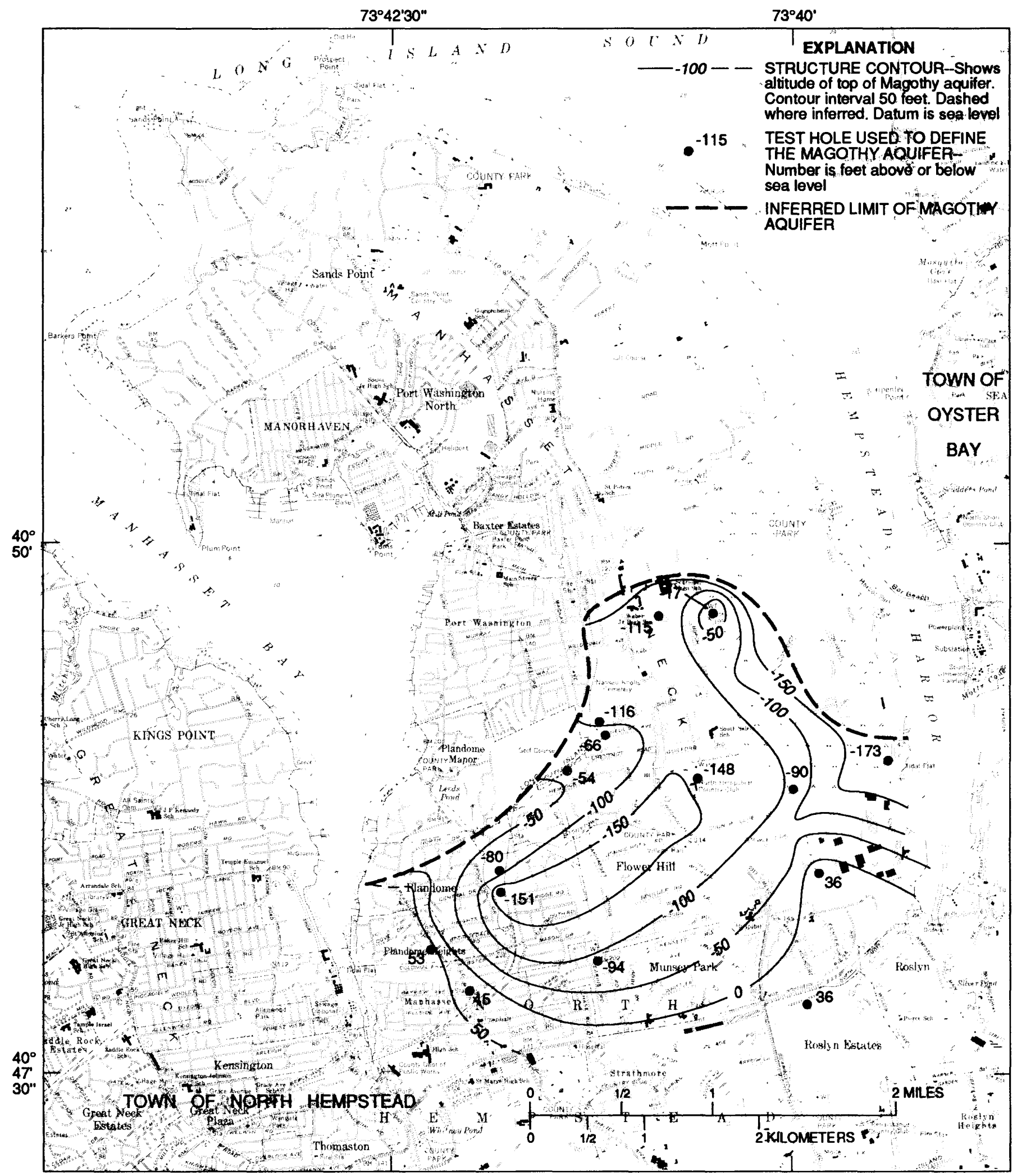

Base from New York State Department of Transportation

Sea Cliff, N.Y., 1:24,000, 1981

Figure 4A.--Altitude of the top of the Magothy aquifer beneath Manhasset Neck. 


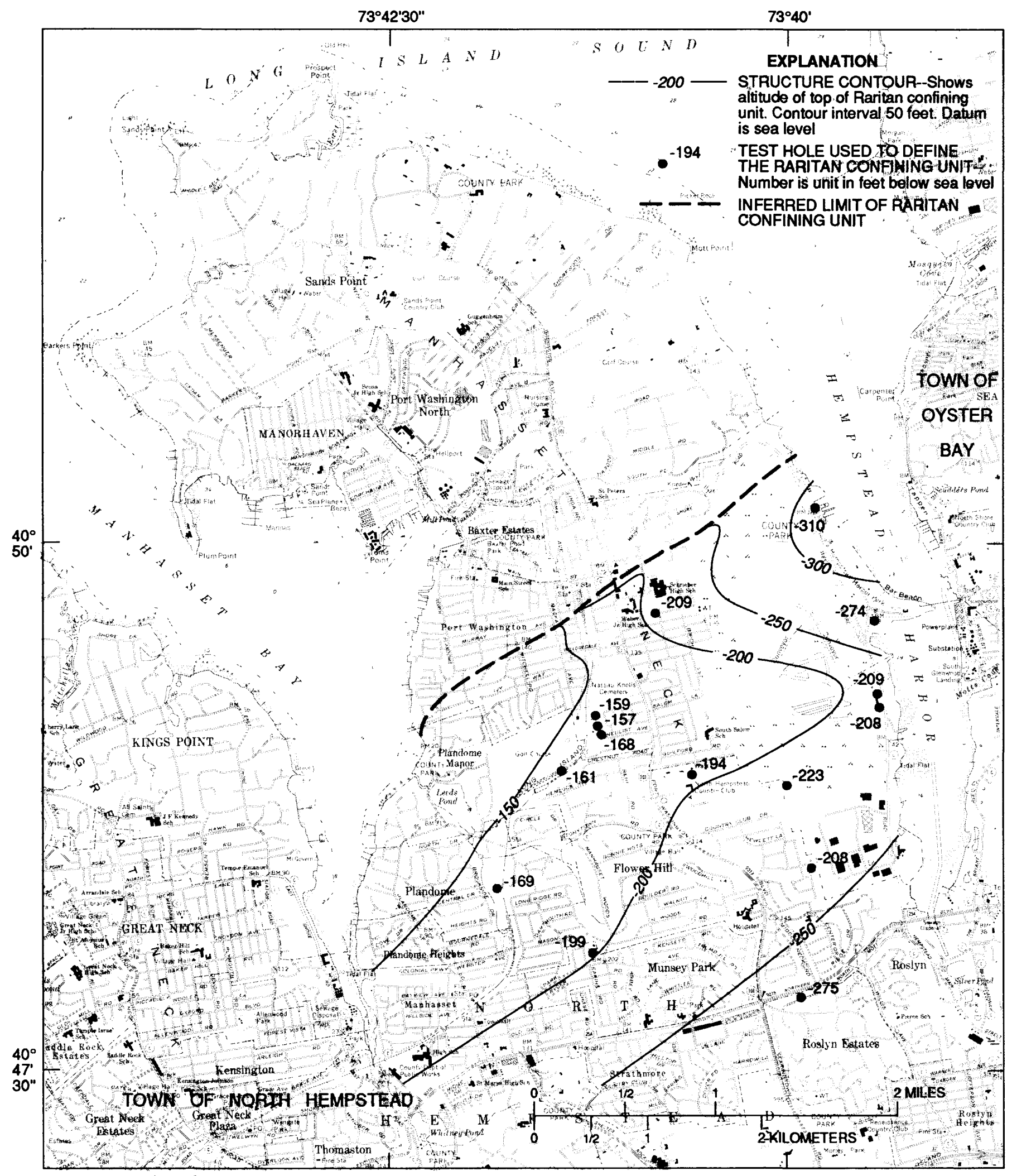

Base from New York State Department of Transportation

Sea Cliff, N.Y., 1:24,000, 1981

Figure 5A.--Altitude of the top of the Raritan confining unit beneath Manhasset Neck. 


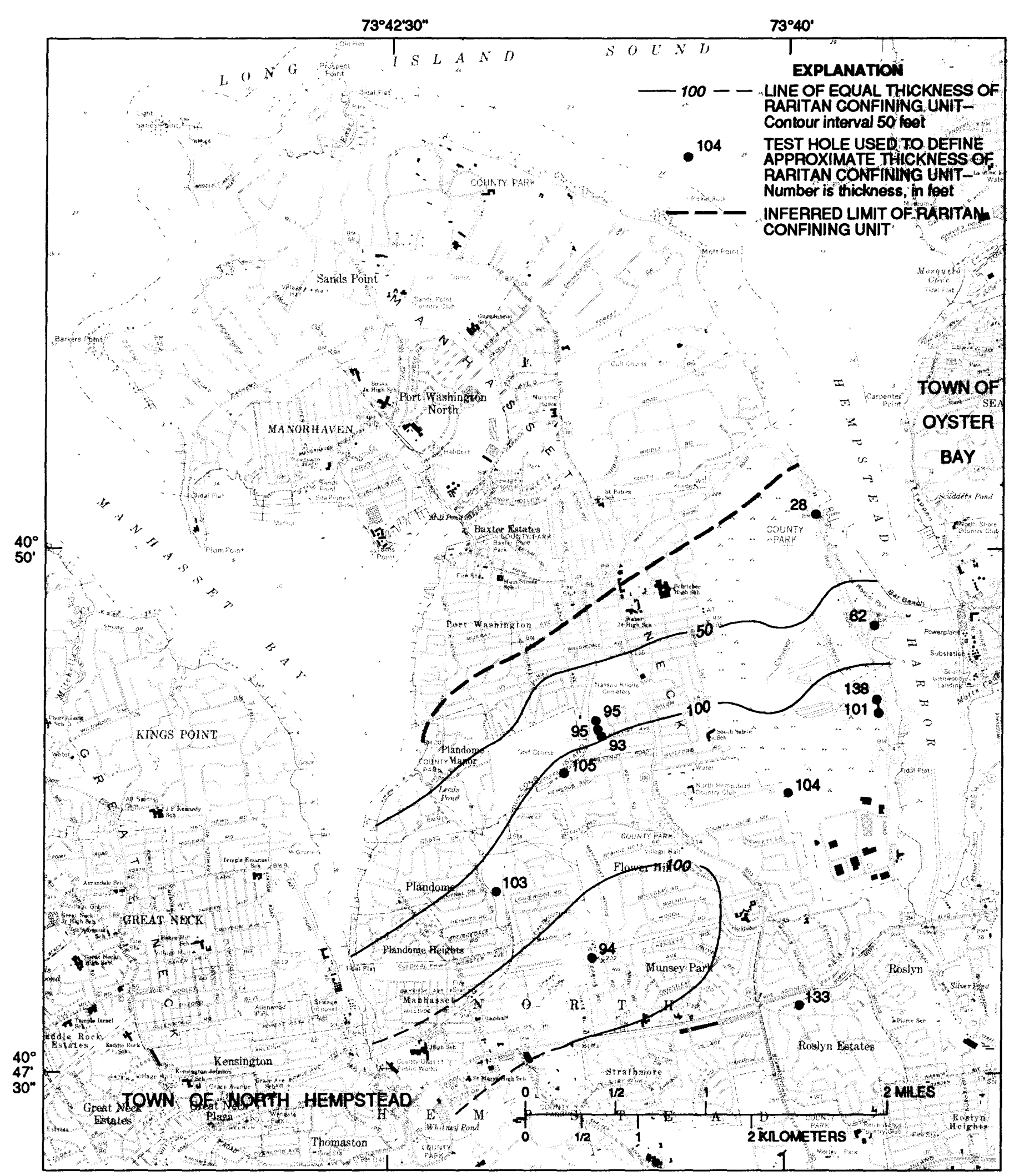

Base from New York State Department of Transportation Sea Cliff, N.Y., 1:24,000, 1981

Figure 5B.--Approximate thickness of the Raritan confining unit beneath Manhasset Neck. 


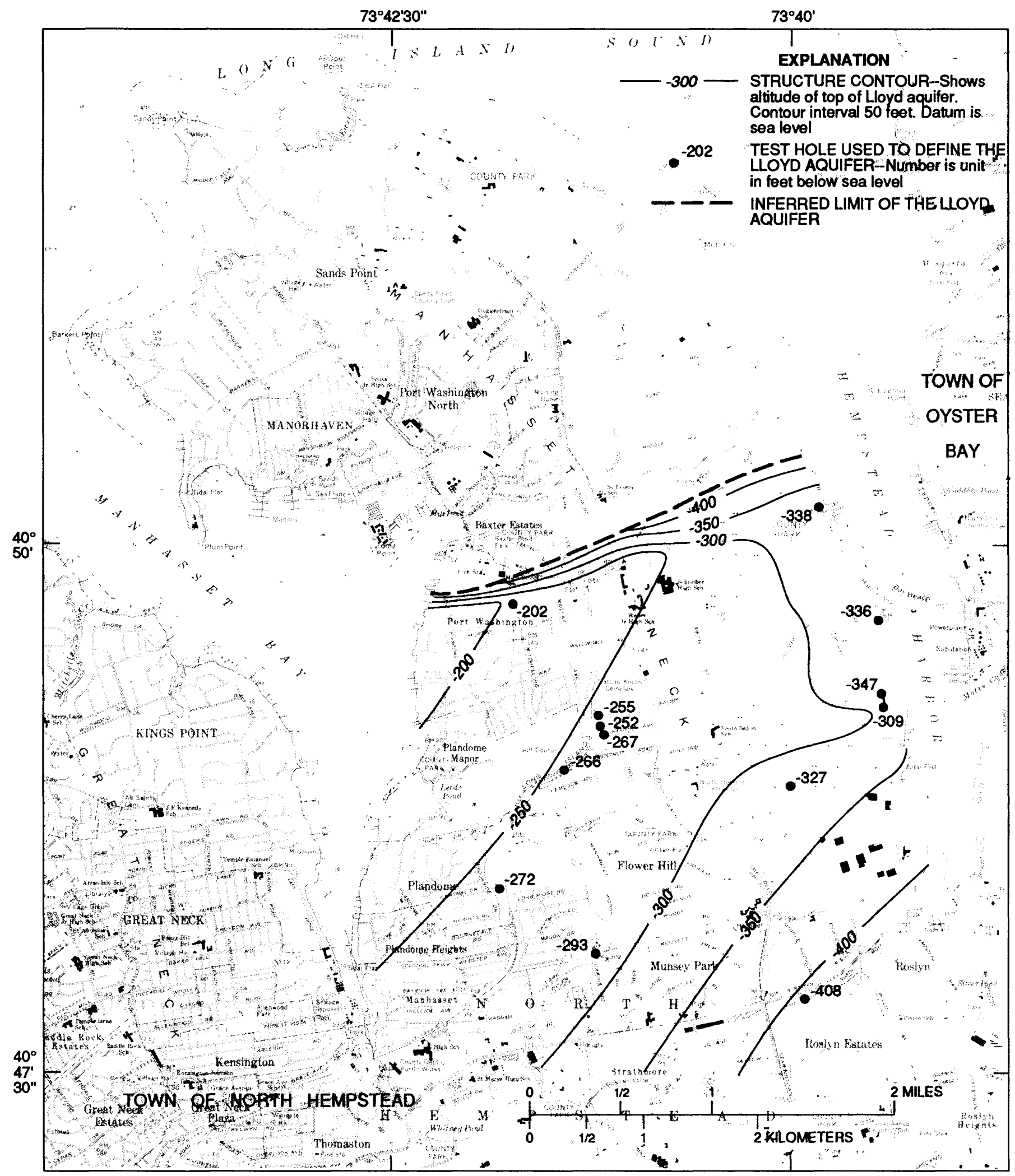

Base from New York State Department of Transportation Sea Cliff, N.Y., 1:24,000, 1981

Figure 6A.--Altitude of the top of the Lloyd aquifer beneath Manhasset Neck. 


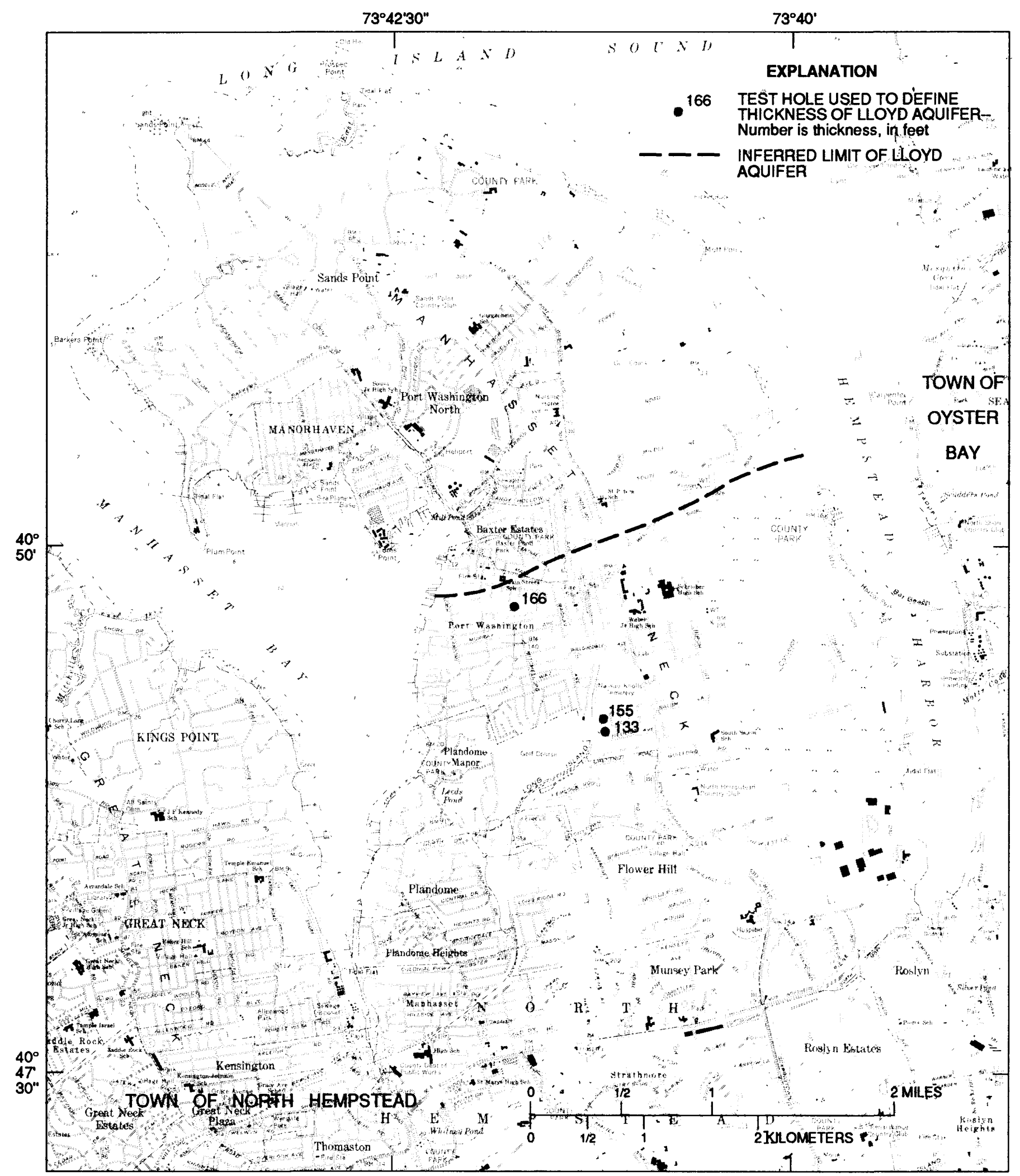

Base from New York State Department of Transportation

Sea Cliff, N.Y., 1:24,000, 1981

Figure 6B.--Approximate thickness of the Lloyd aquifer beneath Manhasset Neck. 


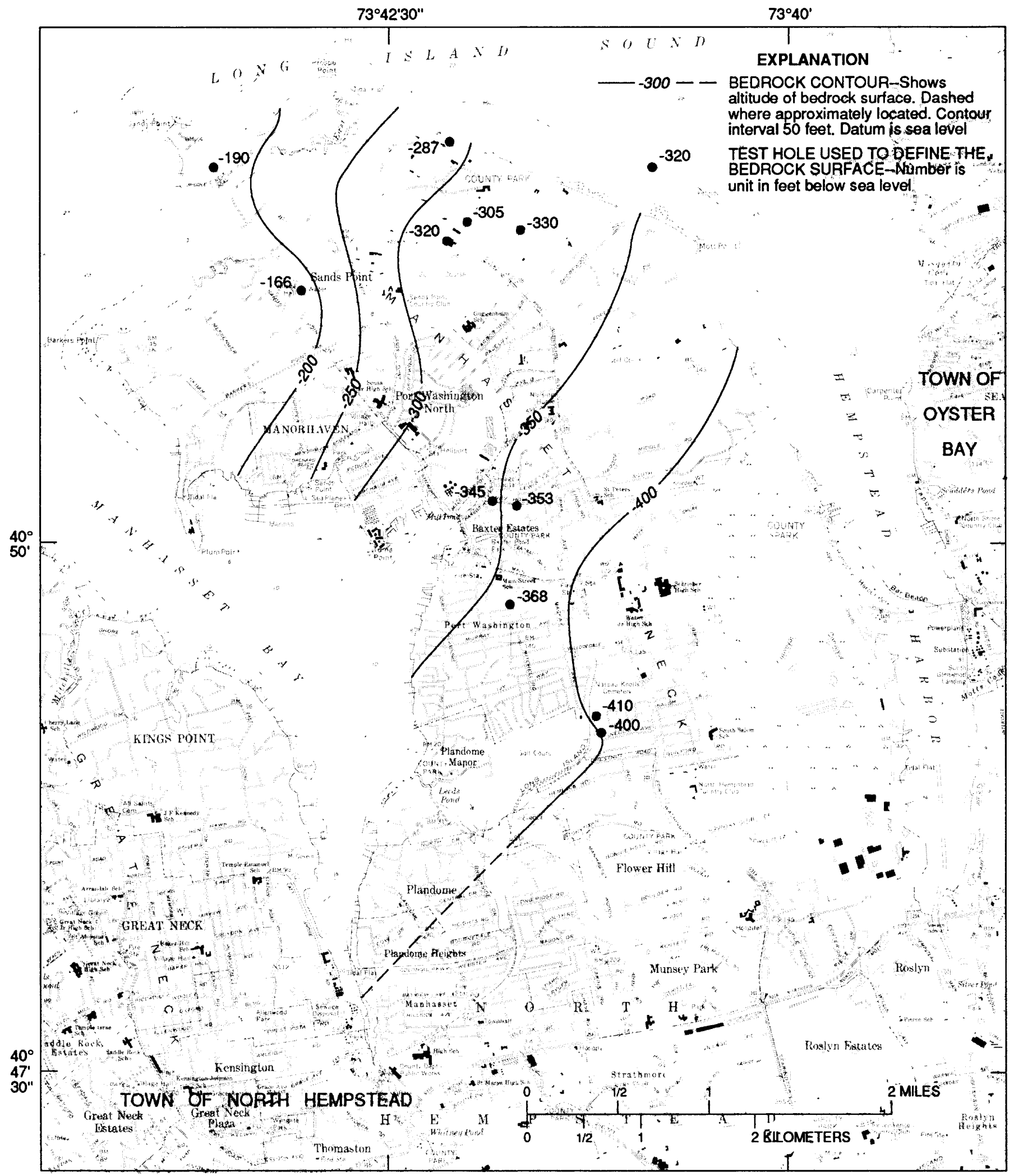

Base from New York State Department of Transportation

Sea Cliff, N.Y., 1:24,000, 1981

Figure 7.--Altitude of the bedrock surface beneath Manhasset Neck. 


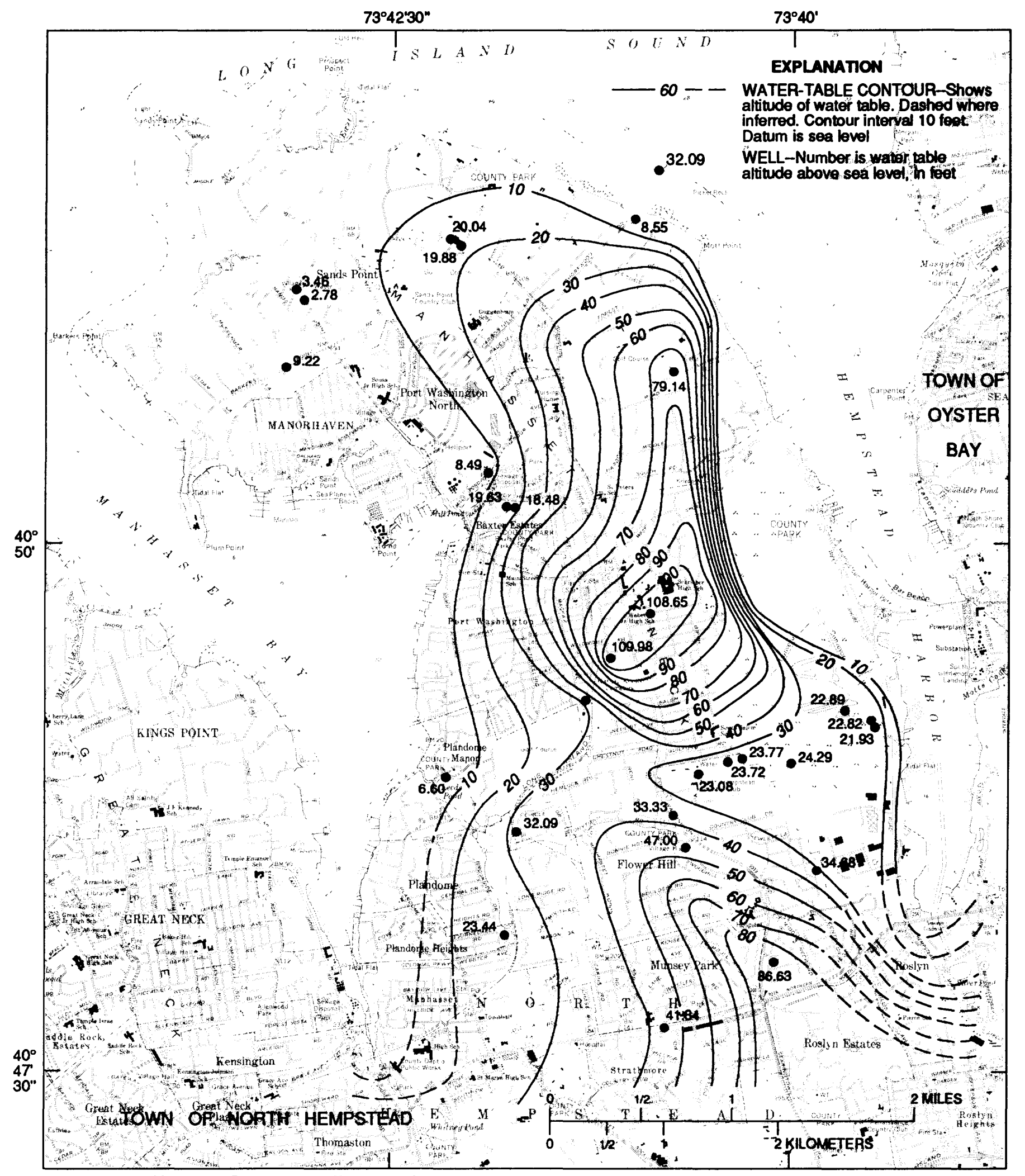

Base from New York State Department of Transportation Sea Cliff, N.Y., 1:24,000, 1981

Figure 8A.-- Water-table altitude on Manhasset Neck, May 29-91, 1985. 


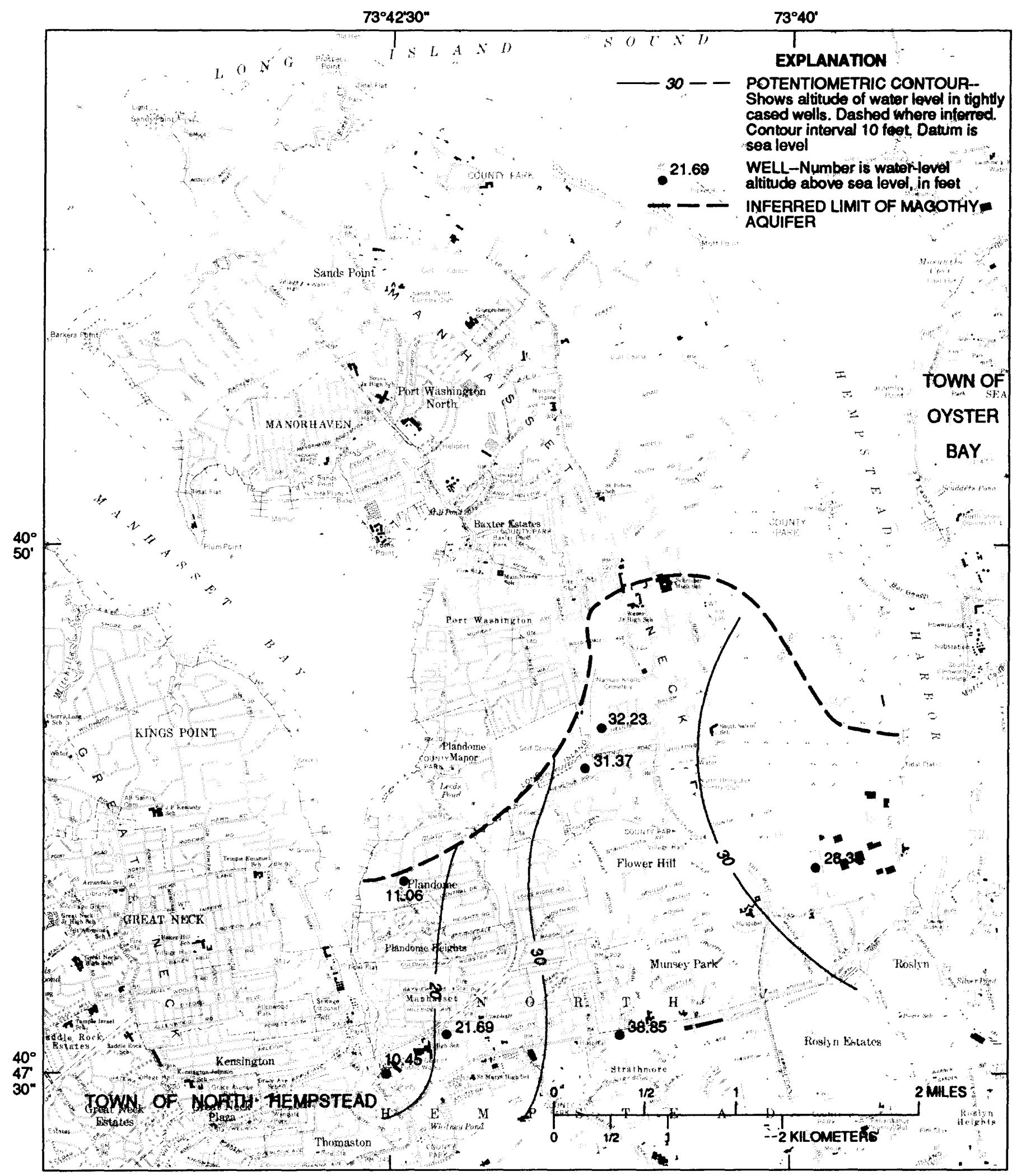

Base from New York State Department of Transportation Sea Cliff, N.Y., 1:24,000, 1981

Figure 8B.--Altitude of the potentiometric surface of the Magothy aquifer on Manhasset Neck May 29-31, 1985. 


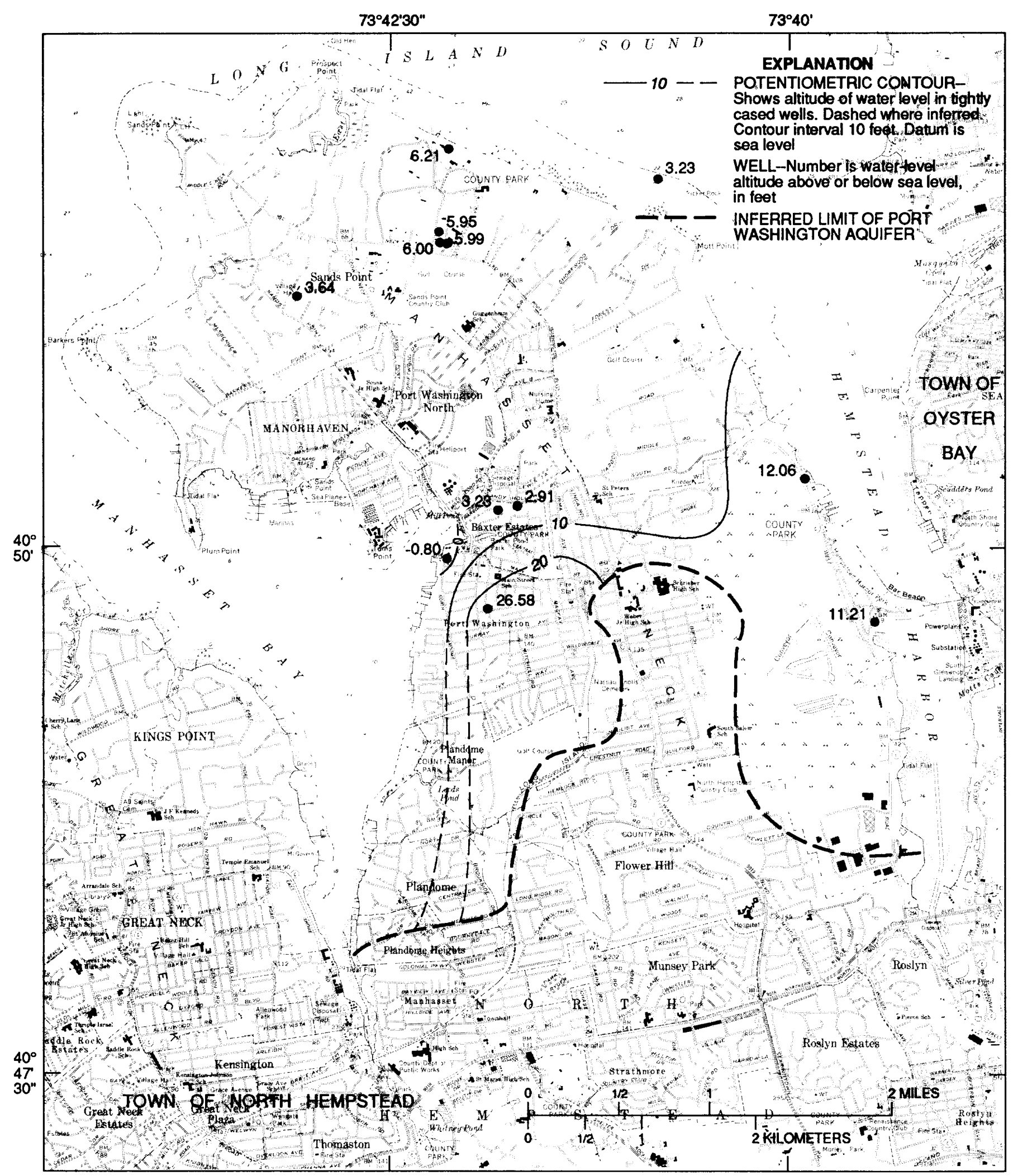

Base from New York State Department of Transportation

Sea Cliff, N.Y., 1:24,000, 1981

Figure 8C.--Altitude of the potentiometric surface of the Port Washington aquifer on Manhasset Neck, May 29-31, 1985. 


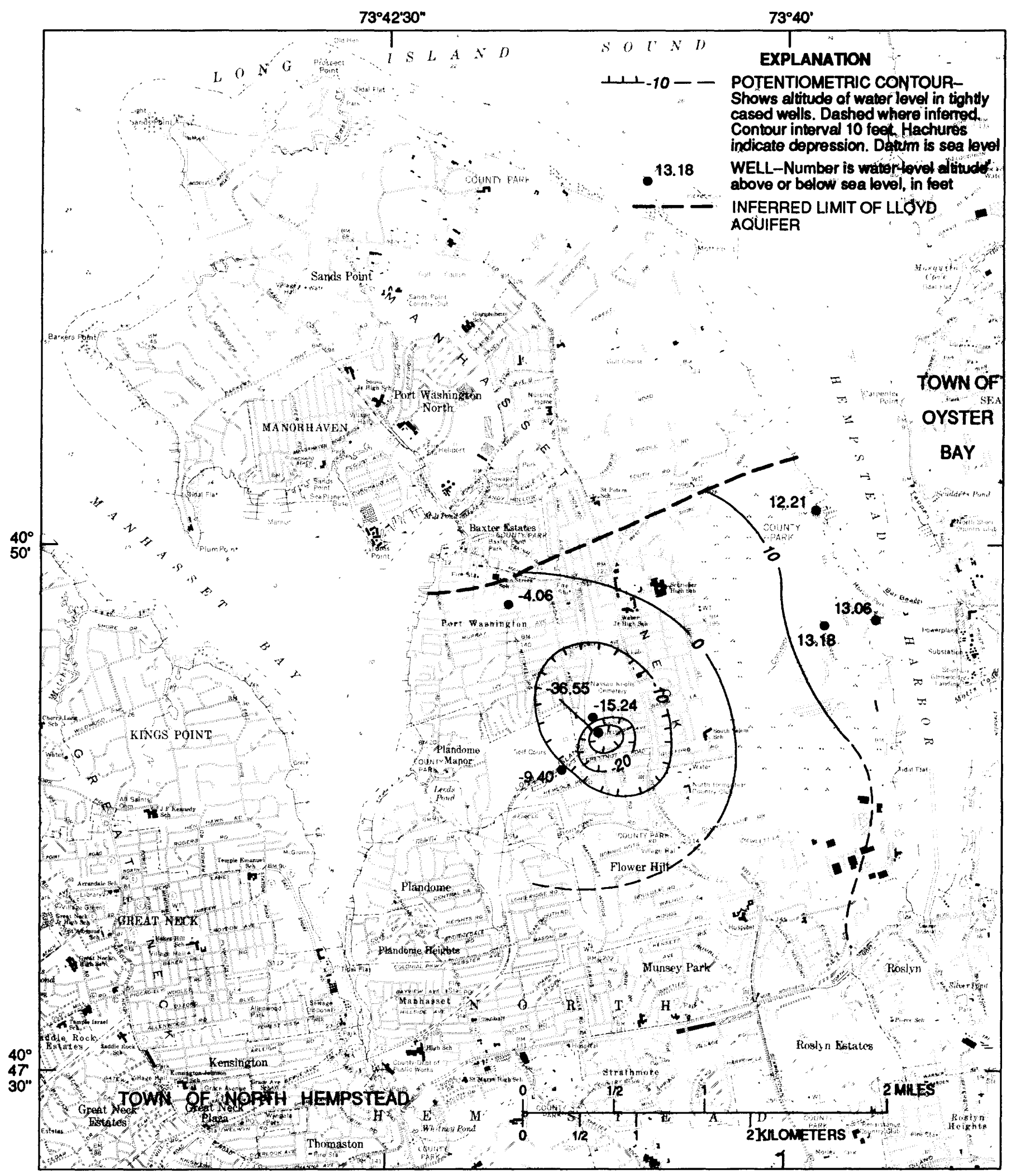

Base from New York State Department of Transportation Sea Cliff, N.Y., 1:24,000, 1981

Figure 8D.--Altitude of the potentiometric surface of the Lloyd aquifer at Manhasset Neck, May 1985. 


\section{REFERENCES CITED}

Fuller, M. L., 1914, The geology of Long Island, New York: U.S. Geological Survey Professional Paper 82, $231 \mathrm{p}$.

Isbister, John, 1966, Geology and hydrology of northeastern Nassau County, Long Island, New York: U.S. Geological Survey Water-Supply Paper 1825, $89 \mathrm{p}$.

Kilburn, Chabot, 1979, Hydrogeology of the Town of North Hempstead, Nassau County, Long Island, New York: Long Island Water Resources Bulletin 12, $87 \mathrm{p}$.

Mills, H. C., and Wells, P. D., 1974, Ice-shove deformation and glacial stratigraphy of Port Washington, Long Island, New York: Geological Society of America Bulletin, v. 85, p. 357-364.

Oliver, J. E., and Drake, C. L., 1951, Geophysical investigations in the emerged and submerged Atlantic Coastal Plain, part 6, the Long Island area: Geological Society of America Bulletin, v. 62, p. 1287-1296.

Perlmutter, N. M., and Geraghty, J. J., 1963, Geology and ground-water conditions in southern Nassau and southeastern Queens Counties, Long Island, New York: U.S. Geological Survey Water-Supply Paper 1613-A, $205 \mathrm{p}$.

Perlmutter, N. M., and Todd, Ruth, 1965, Correlation and foraminifera of the Monmouth Group (Upper Cretaceous), Long Island, New York: U.S. Geological Survey Professional Paper 483-I, 24 p.

Sirkin, L. A., 1974, Palynology and stratigraphy of Cretaceous strata on Long Island, New York, and Block Island, Rhode Island: U.S. Geological Survey Journal of Research, v. 2, no. 4, p. 431-440.

Sirkin, Les, 1982, Wisconsinan glaciation of Long Island, New York, to Block Island, Rhode Island, in Larson, G. W., and Stone, B. D., eds., Late Wisconsinan glaciation of New England: Dubuque, Iowa, Kindall Hunt Publishing Company, p. 35-61.

Suter, Russe11, DeLaguna, Wallace, and Perlmutter, N. M., 1949, Mapping of geologic formations and aquifers of Long Island, New York: New York State Water Power and Control Commission Bulletin GW-18, 212 p.

Swarzenski, W. V., 1963, Hydrogeology of northwestern Nassau and northeastern Queens Counties, Long Island, New York: U.S. Geological Survey Water-Supply Paper 1657, 90 p. 
Appendix. Ground-water levels on Manhasset Neck,

May 29-91, 1985, and related well data.

[Well locations are shown on $\mathrm{p} 1.1$. ]

\begin{tabular}{|c|c|c|c|c|c|c|c|}
\hline $\begin{array}{c}\text { We11 } \\
\text { number }\end{array}$ & $\begin{array}{l}\text { Measuring } \\
\text { point } \\
\text { (feet above } \\
\text { sea level) } \\
\end{array}$ & $\begin{array}{l}\text { Depth } \\
\text { to } \\
\text { water } \\
\text { (feet) }\end{array}$ & $\begin{array}{l}\text { Water level, } \\
\text { in feet above } \\
\text { or below (-) } \\
\text { sea level }\end{array}$ & \multicolumn{3}{|c|}{$\begin{array}{l}\text { Screened } \\
\text { interval, } \\
\text { in feet above } \\
\text { or below (-) } \\
\text { sea level }\end{array}$} & $\begin{array}{c}\text { Screened } \\
\text { geohydrologic } \\
\text { unit }\end{array}$ \\
\hline N35 & 17.24 & 14.01 & 3.23 & -267 & to & -367 & PWA \\
\hline N36 & 38.12 & 34.48 & 3.64 & -200 & to & -214 & PWA \\
\hline N657 & 18.04 & 6.83 & 11.21 & & & & PWA \\
\hline N662 & 16.50 & 3.44 & 13.06 & -336 & to & -352 & L \\
\hline N675 & 7.26 & 8.06 & -0.80 & -259 & to & -276 & PWA \\
\hline N1118 & 146.73 & 67.59 & 79.14 & 73 & to & 65 & UG \\
\hline N 1120 & 116.15 & 69.15 & 47.00 & 21 & to & 16 & UG \\
\hline N1482 & 10.77 & 6.38 & 4.39 & -137 & to & -140 & PWC \\
\hline N1483 & 10.45 & 2.63 & 7.82 & -85 & to & -88 & PWC \\
\hline N1484 & 10.12 & 1.63 & 8.49 & -39 & to & -41 & UG \\
\hline N1715 & 102.86 & 139.41 & -36.55 & -329 & to & -379 & L \\
\hline N1716 & 108.34 & 123.58 & $-15 \cdot 24$ & -324 & to & -374 & L \\
\hline $\mathrm{N} 2030$ & 108.39 & 76.16 & 32.23 & -88 & to & -113 & M \\
\hline N2052 & 158.31 & 129.93 & 28.38 & -116 & to & -166 & $M$ \\
\hline N2269 & 113.24 & 82.72 & 30.50 & -98 & to & -102 & UG \\
\hline N2635 & 43.04 & 16.46 & 26.58 & -110 & to & -114 & PWA \\
\hline N3742 & 138.15 & 104.82 & 33.33 & -90 & to & -120 & UG \\
\hline N4223 & 197.57 & 174.49 & 23.08 & -85 & to & -138 & UG \\
\hline N4389 & 87.60 & 70.84 & 16.76 & -70 & to & -145 & PWC \\
\hline N4859 & 31.35 & 28.44 & 2.91 & -323 & to & -353 & PWA \\
\hline N4860 & 23.22 & 3.59 & 19.63 & -42 & to & -71 & UG \\
\hline N5530 & 63.20 & 67.26 & -4.06 & -309 & to & -319 & I \\
\hline N5876 & 85.85 & 54.48 & 31.37 & -68 & to & -138 & M \\
\hline N6031 & 30.33 & 26.87 & 3.46 & -6 & to & -8 & UG \\
\hline $\mathrm{N} 6033$ & 118.02 & 8.04 & 109.98 & & & & UG \\
\hline N6087 & 22.71 & 4.23 & 18.48 & -43 & to & -72 & UG \\
\hline N6 117 & 156.75 & 48.10 & 108.65 & 30 & to & 28 & UG \\
\hline N6282 & 102.22 & 96.23 & 5.99 & -282 & to & -292 & PWA \\
\hline N6342 & 100.99 & 80.95 & 20.04 & -86 & to & -88 & UG \\
\hline N6346 & 51.98 & 38.80 & 13.18 & -311 & to & -321 & L \\
\hline
\end{tabular}

1 PWA, Port Washington aquifer; L, Lloyd aquifer; UG, upper glacial aquifer; PWC, Port Washington confining unit; M, Magothy aquifer. 
Appendix. Ground-water levels on Manhasset Neck,

May 29-31, 1985, and related well data (continued)

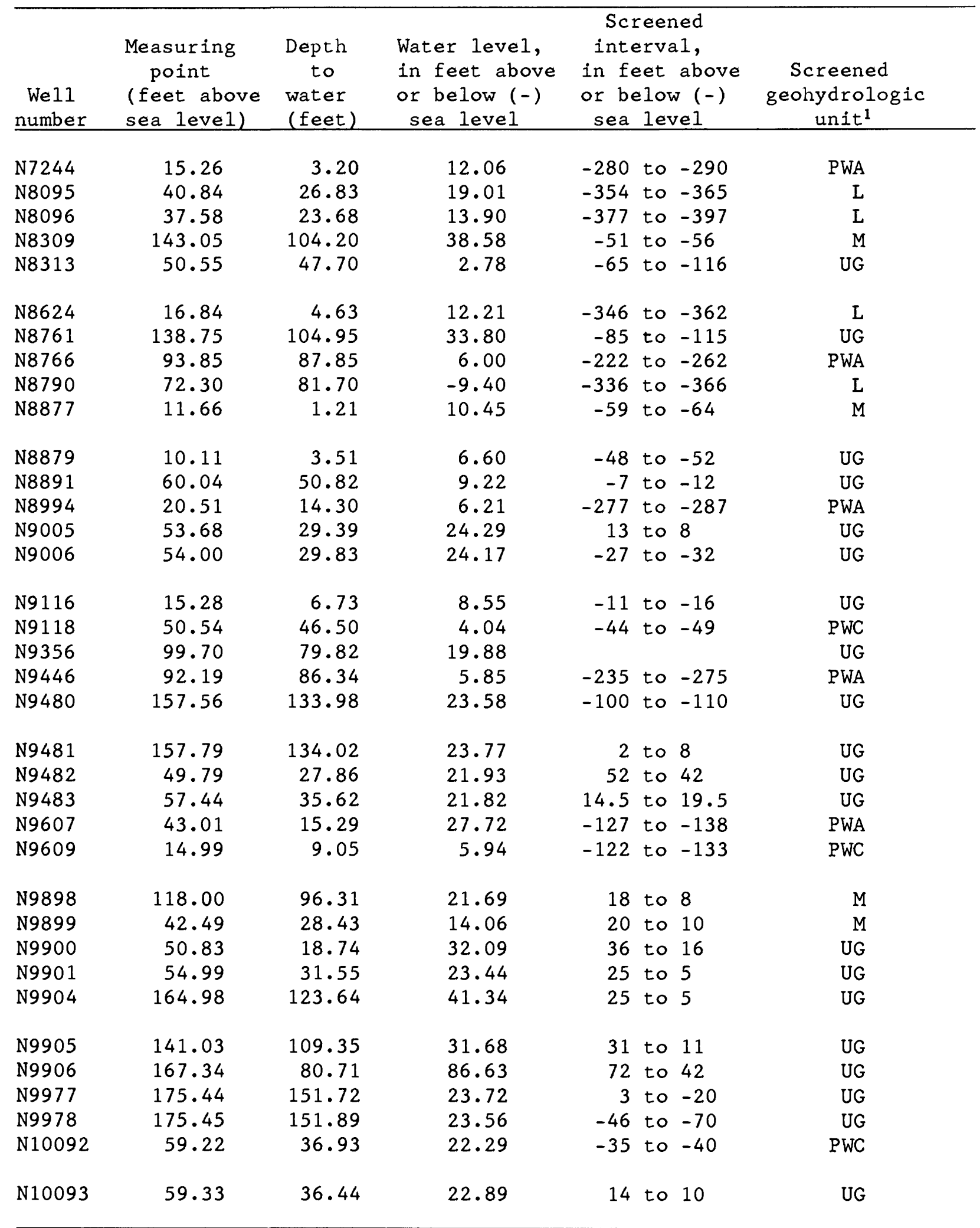

